NOVA

University of Newcastle Research Online

nova.newcastle.edu.au

Rolls, Alistair; Rechniewski, Elizabeth "Uprooting the chestnut tree: Nausea today" Sartre's Nausea: Text, Context, Intertext p. 1-27 (2005)

Available from: http://www.brill.com/products/book/sartres-nausea

Accessed from: $\underline{\text { http://hdl.handle.net/1959.13/1055600 }}$ 


\title{
UPROOTING THE CHESTNUT TREE: NAUSEA TODAY
}

\author{
ALISTAIR ROLLS, \\ ELIZABETH RECHNIEWSKI
}

2005, the centenary of Jean-Paul Sartre's birth, is an opportune time to re-engage with his most famous creation, a book that has marked readers around the world since its publication in France in 1938. This is a time to celebrate the ongoing success of this most famous of French thinkers, and to re-consider what Nausea has come to 'mean' and what the future holds for it as a reading, teaching and researching experience. Twenty-five years since his death, everything is still to be said about the most renowned of his orphans. For Sartre's masterpiece of French fiction still has the potential to proliferate academic discourse across university departments and across continents. The essays that follow do not treat Nausea as a set of readings that need to be conveyed or passed on to posterity; they explore the living text, exposing its potential to generate new discourse well into the new millennium.

In April 2000 the French television network Arte aired, as part of their series Le Sens de l'histoire, a programme dedicated to Jean-Paul Sartre. The programme - a discussion of Sartre the philosopher and phenomenon - was prefaced by a short film directed by Guy Seligmann, Sartre: Vingt ans d'absence. This film brought together leading French philosophers and Sartrean academics in order not so much to discuss twenty years of the void left by Sartre's death in April 1980, but his continued importance in the twenty-first century. Michel Contat, a researcher with the CNRS, opens the film by challenging the need to "bury Sartre again" that seemed to him to be prevalent in the French media at the time the film was made. In questioning the thesis of Bernard-Henri Lévy's prodigious volume, Le Siècle de Sartre (published in 2000 in Paris by Grasset), in which, Contat resumes, a desire is expressed to redeem Sartre from purgatory, he suggests that it is absurd to talk of purgatory in our discussion of a philosopher whose posthumous works have been so widely collated and published, and whose whole oeuvre is still so avidly read. This would, indeed, appear to be the very opposite of a writer's purgatory. We use the word 'writer' advisedly; for what is left of Jean-Paul Sartre - and Seligmann's documentary is at pains to highlight this point (with close-up shots of the various editions of Sartre's works) - is a daunting collection of books.

The question that the film raises for the reader of Nausea is the eternal one: is this a work of philosophy or a novel? Sartre: Vingt ans d'absence puts forward an ambivalent image of Nausea. It showcases the novel, giving it pride of place (it is the first text discussed after Contat's preamble) and quoting it both directly and indirectly (and it is important to state that we consider Sartre's own discussion of the text to be indirect commentary despite his privileged relationship to the novel, as writer); it also emphasises Nausea as philosophy, depicting its status as novel as almost incidental, as a vector - albeit the ideal one - for Sartre's early philosophy. In footage of the two mandarins of Existentialism sitting before a group of the next generation of French philosophers (Beauvoir is shown sitting behind Sartre, as if both intently listening to him and watching over him), Sartre describes nausea as a feeling that comes with existing in the world; it is, he explains, a pathological intuition of the way things are. He had never felt nausea, or experienced Roquentin's visceral reaction in quite this way. Had his thoughts been clearer, more fully formed at that time, he would have 
written a philosophical text. In order to convey his thoughts on existence in the world - pour le rendre au lecteur - he needed to adopt the apparatus of the novel, une forme plus romanesque. This, too, is double-edged: Nausea could not have been (i.e. in the form that exists today, as the novel that is the focus of our discussion), had it not been for the reader; and yet the role of this reader, and Sartre is quite clear on this, is subordinated to that of the writer. Nausea is portrayed as a sketch of a phenomenology that will come of age in its 1943 avatar, Being and Nothingness. The Chestnut tree roots hold the key. Sartre was seeking to expose Roquentin's guilt (of existing) in the form of a detective novel (interestingly, Sartre's status as reader is not discussed in the film, and he was a great reader of this particular genre); he veiled his thoughts in a web of novelistic techniques in order better to unveil them, exposing the guilty party with the crushing evidence that is contingency. The novel is a necessary form in 1938 if he is to impart his feelings (Beauvoir's role in the fictionalising of Nausea is - logically - not broached in this film). The tree roots are the key, then, and the film quotes this famous passage at length, with close-up shots panning around a jardin public (in Paris, interestingly). At no point is it suggested that either the writer (either as novelist or thinker) or the reader (as fan of literature or philosophy) actually gain from the novelistic (or diary that becomes novel) form adopted. Philosopher Jean-Toussaint Desanti sees in Nausea a striking rendering of phenomenology "en situation, sur le tas", in which the role of Roquentin is to provide the eyes through which the reader will discover the world not as we are told that it is but as it actually exists. The fictional form, it would appear, has the perverse effect of conveying reality. ${ }^{1}$

In this volume, it is our contention that the novel has an existence that lies apart from its author. It is, indeed, interesting that, in the twenty-first century, a novel should continue to exist in relation to which it is still necessary to discuss Barthes' famous appropriation of Nietzsche. It is not that we wish to join those grave-digging commentators against whom Michel Contat argues for the continued life of Jean-Paul Sartre. In some form, however, it seems to us necessary to allude to the death of the author in order to breathe some life back into Nausea as novel.

For a student reading Nausea, and possibly Sartre, for the first time, the sheer weight of knowledge and writings for which this text has become something of a flagship can be daunting. For the teacher, too, the challenge is considerable, and it is doubtless to some degree for this reason that Nausea has tended to become a tool or vehicle for studying clearly defined and demarcated fields of knowledge, such as French culture or philosophy, by which it then becomes subsumed. This tendency can be seen variously as logical, defensible or lamentable. As a fixed part of the French syllabus in secondary and higher education, it is a hugely important text: within the discourse of French studies, Nausea is prefixed with such epithets as 'a seminal novel of the twentieth century', and is a valuable point of entry into la pensée sartrienne. It is a novel, in short, that has been appropriated by French studies around the anglophone world as a way of teaching Existentialist thought. In France it continues to endure within a philosophical framework. In Sartre: Vingt ans d'absence high-

\footnotetext{
${ }^{1}$ We might think here of strategies inside the novel itself that exploit this fictional reality / external reality tension. The 'Editors' note', for example, stands ostensibly as a proof of the text's status as 'genuine' diary; by following a well established literary tradition of such devices, however, Nausea sends up - and, in fact, emphasises - its status as fiction (Nicholas Hewitt, for example, discusses this eighteenth-century tradition in his article "Looking for Annie”). Indeed, one might argue that the 'Publishers' note, links Nausea intertextually to such particular examples of the French canon as Laclos' Les Liaisons dangereuses.
} 
school teacher Charles Pépin bears witness to the difficulty of making Nausea accessible to French adolescents. They are more able to engage with the image of a philosopher sitting in a café, smoking a pipe, drinking coffee and popping amphetamines than with the prose voice of Antoine Roquentin. But, admits Pépin, Nausea is still - with or without amphetamines - a powerful tool for explaining what it means to exist. But what of Nausea the novel? Our aim here is to avoid too narrow a categorisation of the text and to open it up to new approaches, new functions and new purposes.

In the context of the modern Anglo-Saxon university system, with its constant appeals to interdisciplinarity, permeability and economic reality, it is clear that Nausea can exist perfectly well outside the disciplines of French Studies and Philosophy. It is in the interest of broadening the appeal of Nausea that we have collected together in this volume authors whose approaches to the text spring from three principal areas: French Studies, Philosophy and English/Comparative Literature. All three discipline areas have their own contribution to make in terms of the written text (the textual strategies at work within the novel), its context (be it literary, cultural or philosophical) and the intertextual web within which it is situated. In this volume, then, Nausea will be considered by academics from diverse backgrounds both for what they can do for it and what it can do for them.

\section{'Nausea' as Text}

As has already been suggested, Sartre, unlike his character Anny, has not spent the last twenty-five years 'outliving himself'; he has continued to act on the world stage as a philosopher, political commentator and novelist. The works that continue to be published (both under his own name and by philosophers and literary scholars) attest to his importance as a figure greater than the sum of his collected works. Perversely, the awe in which Sartre is held has been one of the key factors behind the tendency to delimit the textual possibilities that a reading of Nausea should bring forth.

The famous words "J'étais Roquentin” (“I was Roquentin”), coupled with the fact that Sartre has become too big for us to consider him as dead in any but the most physical senses, have resulted over the years since the novel's publication in a sense that there is something that Nausea is about. In particular, the declaration that Sartre "was Roquentin" acts to foreclose interpretative analyses of Nausea. The major problem in seeking to make Sartre and Roquentin coincide is that, as scholarship shows, the Sartre who wrote Nausea has become synonymous with the Sartre of 1943 who published Being and Nothingness. Roquentin has, thus, acquired philosophical baggage - and Nausea a whole philosophical framework - that Sartre's own words belie. To conflate the pre-war Sartre and the wartime Sartre appears to contradict his admission that at the time of writing Nausea he chose the novelistic form because his own understanding of existence was not clear enough to him to allow him to ideate his thoughts in the form of a purely philosophical work. If he were Roquentin, then we might suggest that this undermines scholars' attempts to read Nausea via Being and Nothingness (i.e. by understanding Nausea through Being and Nothingness we are perhaps guilty of putting the cart before the horse: we should use Nausea to explicate Being and Nothingness) ${ }^{2}$ If we assume that Roquentin represents Sartre, we must,

\footnotetext{
${ }^{2}$ This is, of course, not a suggestion that we wish to push too hard. To apply Being and Nothingness in order to explicate aspects of Nausea can, of course, be not only relevant but immensely fruitful, even
} 
therefore, consider that he was just one historically specific instance of Sartre's incarnations. Bernard-Henri Lévy writes at length on this point. In Le Siècle de Sartre, Lévy demonstrates the extent to which Sartre changes between the writing of Nausea and the position he adopts vis-à-vis humanism after his experiences as a P.O.W. during the Second World War. Indeed, according to Lévy, if Sartre were Roquentin, he was also - just a matter of a few years later - the Autodidact. And yet, if we read his post-Liberation lecture, Existentialism is a Humanism, which he gave at the club Maintenant in Paris in 1945, we find a Sartre who is still at pains to distance himself from the cult-of-humanity humanism, according to which men are to be praised for the wondrous achievements of mankind. By placing his own humanism within the context of a subjectivist philosophy (there is no other universe than that which is human, he writes), Sartre not only distances himself from the Autodidact; he also critiques certain misinterpretations of Nausea. As early as 1945, then, Sartre himself claims Nausea to be a misunderstood text, a victim, as it were, - like Existentialism itself (a word which he declares to be all but meaningless in the mouths of most people) - of its own success.

There is also a philosophical problem at the root of Sartre's claim. To what extent can ontological parallels be drawn between Jean-Paul Sartre and Antoine Roquentin? In what way can he have been Roquentin? If we consider Nausea to be a philosophical novel inasmuch as its narrative tension derives from the text's constant negotiation of the philosophy / fiction dichotomy, then we should do well to question its way of existing as novel. As a being for-itself Sartre existed before he could be said to have an essence. There was no essential Sartreness possible until the day of his death, at which time he finally coincided with the sum total of his past actions. Be that as it may, in order for Sartre(ness) to be said to have some kind of meaning, it is necessary for inferences to be drawn by Others (it is we who must decide what he means). To equate Roquentin and Sartre is to suggest that the novel can be said to 'mean something' upon its completion. And yet, this seems to us to be missing a vital stage in the process of 'meaning'. The novel is initially drafted according to a plan; to this extent, its essence precedes its existence. As the writer puts pen to paper, however, the text begins to develop - to a certain extent - of its 'own free will'. That is to say that there is a degree to which the formulation, in words, of an idea takes that idea into a written form that is removed from the author's initial design. Much has been said in reference to Nausea of the tension between the resultant novel and the philosophical treatise that was at the centre of its inception (and which Sartre himself admitted was too inchoate in 1938 to be expressed other than by fiction). JeanToussaint Desanti paints a picture of a thinker writing too fast for his thoughts (of a cogito, as it were, spilling out beyond the control of its body, perhaps to be written before it can be recaptured), composing his text au courant de la plume, or 'as the pen took him'. So, despite the best laid plans, it seems that a text begins to come alive (as an existent) even as the author tries to forge it according to a pre-defined telos.

And upon the novel's completion? Whilst it is true that the novel can be likened to the piece of jazz in Nausea inasmuch as we readers cannot touch it: if we burn our copy, it cannot be said that Nausea no longer exists. As a series of words, it is untouchable. It is not for this reason, however, that its meaning is set in stone. The words can only produce meaning in the minds of Nausea's readers. And so, it is upon its passing into the public domain (the moment of its separation from authorial power)

within the framework of a specifically literary study of the work (see Alistair Rolls' chapter in this book). 
that it exists fully. For it is at this moment that is become a being for-Others, exposing itself to those who will see it as it really is.

The existential(ist) novel, like any being for-itself, can only exist in situation. Unlike Descartes' dualism, according to which one thinks therefore one is, existentialist man 'thinks therefore he is what he is not and is not what he is'. Nausea is a projection onto the world, frozen beyond the control of authorial consciousness, and accessible only to the Other. An existential(ist) novel is, therefore, one whose meaning(s) must be constantly (re-)negotiated not at the interface of the author / text but at that of the text and its readers. The reader is the Other who holds the key. This empowers the reader - who acquires the authority and freedom to dare to infer meaning - whilst retaining the novel's freshness: the reader can only ever understand the text's 'shallow level of being', to borrow a term from Neil Levy's Sartre; the novel cannot be in a 'profound' way any more than can a human being. To seek to impose a retrospective essence on a living text is, to continue our use of Sartrean vocabulary, to read in bad faith. As readers of Nausea we must seek to apprehend the text in the ways that it is, in full knowledge of the fact that we can only ever unveil layers of possibility. To impose hegemonic meaning upon a novel (to tell people what 'it is all about') is to glue it in place.

It is the aim of this volume to give readers access to a number of potential readings. For the novel does have meanings. Just as the fact that we who are writing this introduction are not French lecturers in any essential sense, there is clearly a way in which we are French lecturers. And so it is for Nausea: it is not because it is not only and essentially a treatise on contingency that it is not a treatise on contingency. This realisation that the meanings of the text are there to be made does not devalue the novel - or Sartre via the novel - rather it liberates the text, providing the rigid framework of existing structures from within which it can be free.

In the light of these opening comments, the first chapter of this collection is a remarkably liberating reading. Lawrence Schehr draws on all his expertise (in the fields of the nineteenth- and twentieth-century French novel, Queer Theory and even - French cuisine) to reread the figure of the Autodidact. Just as the self-taught man becomes one with the books that he internalises, he leaves himself exposed to a keen eye. Schehr opens him up, exposing Sartre's description of him for what it is. For the Autodidact is there to be read, and it is almost as if Sartre is taking pleasure in surrounding him with words that he knows the reader will misconstrue. Schehr does not draw our attention to the words of the Corsican librarian, who attacks the Autodidact for his violation of the schoolboy, in order to offer up the possibility that Roquentin may himself be a homosexual; rather, he exposes the scene in the library as the climax of a long sequence of exchanges between Roquentin and the Autodidact, in which the (body-)language is not only suggestive of homoeroticism but actually simulates sexual intercourse. The reader can only feel some of the Autodidact's shame: we have read the pages but have not understood the words. Schehr points to Sartre's use of juxtaposition, through which a glimpse of truth is hushed up, buried beneath apparently clumsy bursts of, often obscene, monologue. The text's textuality is shown to be its sexuality. Nausea has a coy, provocative side; it will kiss and tell as long as you do not avert your gaze.

A good example of this is the scene where the two men meet for lunch. It does not take a massive leap of imagination to read the Autodidact's 'love of men' as an avowal of homosexuality. Where Schehr's reading is so powerful is in its revelation that this admission of humanism is a rewriting - by a man who is made of text - of events that have already taken place in Nausea. Readers are once again made to 
realise that they were indeed present at the moment of intimacy between men which the Autodidact recounts. This diary that Roquentin designs to be a setting out of events in a permanent present (the truth aired en direct) becomes a forum where the Autodidact and Roquentin revel in invented tales of their past (the former as a P.O.W. and the latter as Anny's lover). This monument to bad faith all begins to look like an avoidance of sexuality; or, rather, sexuality becomes redirected, veiled and transposed. Schehr's conclusion is almost a remake, the last instalment of 'Sex in the Library'. As such, this chapter sets the scene perfectly for this collection of essays: Schehr's translation of what is on the menu at lunch is picked up by Debra Hely (who arrives at similarly homoerotic conclusions by intertextual means), whilst the caress in the library will be revisited in Rolls' hands-on reading. As Schehr notes, the Autodidact's language "does not seduce through the contents but through the form"; and it is this language of forms that Schehr enables us to read.

The remaining chapters in this section all address the question of Roquentin's nausea, each approaching the question from a different perspective. George Woods' chapter is all about perspectives; her chapter posits nausea within the framework of the visual arts, revealing the root of the nausea to lie in the tension created by Roquentin's opposition of visual perception and mental conception. In so doing, she questions 'meaning' as the application of abstract understanding to a world-canvas where objects are simply present. Tom Martin's chapter acts as a rejoinder, seeking to investigate the way in which the world may be considered to be always already meaningful. And finally, Peter Poiana elevates the nausea to the level of protagonist; by approaching the text from both a Freudian and Lacanian angle, he is able to offer a different analysis of the body language that is central to Schehr's reading whilst rehabilitating the discourse of psychoanalysis as a means of opening the Sartrean novel.

Woods demonstrates how meaning in Roquentin's world depends on the correct light settings. Nausea gradually exposes as illusory the feeling of well-being that comes from moody, ambient lighting; Roquentin will reject the dimmer-switch, favouring instead the close-ups on individual objects picked out by the contrast of bright light on a dark background. Diffused light, Woods reveals, offers a visual overview that the brain must supplement; mental constructs seek to impose an understanding of what has been perceived by overlaying a map of abstract 'knowledge'. Meaning is thus shown to be created by an individual reading the real world through a preconceived set of values. The diffused lighting that allows this conception of the world becomes, for Roquentin, a sinister fog. The atmosphere of Bouville, when the nausea overwhelms him, replicates the darkly realistic description of noir literature, in which life is shown in all its brutality and nuances (in the noir novel, as in Nausea, life is not 'black and white'; events are always ambiguously couched in shades of grey). By contrasting the uses of light in the novel, which are in turns Cubist and Impressionist, Woods arrives at a definition of the nausea as Roquentin's “[rumination] over the gulf between perception and interpretation.”

Tom Martin follows on from Woods by introducing a third element into the meaning equation. For it is not enough for us to say that an object's meaning is a mental appraisal made by the subject of that object's existence in the world; that we are able to consider the object in abstract terms is made possible by an understanding of meaning which is independent of us. Meaning is, Martin argues, intersubjective; and, as such, it precedes our individual existence. The nausea is therefore Roquentin's realisation that meaningful relations are not born of necessity or internal logic. Where Martin seeks to innovate is not in a search to justify a reading of nausea as a state that 
accompanies a revelation of the nature of existence; rather, he aims to explain the disappointment that Roquentin feels, which seems to stem from a set of implicit $a$ priori expectations of how the world ought to be. He discusses, in philosophical terms, the way in which meaning is generated by the interaction of subject and object (i.e., the being in-itself cannot 'mean' in the absence of a subject, but neither can the subject bear sole responsibility for producing meaning in the object). The meaning that we need in order to act in the world (our projects help us to create meaning but we are also shaped by them ${ }^{3}$ ) is made possible by our interaction with others. Martin considers Roquentin's problem to lie in his Manichean attitude towards meaning, according to which it shall be essential or it shall not be. The fog that Woods reads in terms of diffused light, and which accompanies the nausea, becomes, in Martin's analysis, the grey area through which Roquentin cannot find his way. And it is in this grey area that the possibility for some kind of meaning lies.

In the final paper of this section Peter Poiana follows what appears to be a familiar trajectory: like Martin, he begins his reading with the pebble scene and, like so many philosophical interpretations of Nausea, concludes with the famous incident of the Chestnut tree. In 'The Subject as Symptom in Nausea', however, Poiana offers an analysis of Roquentin's drives that differs radically from phenomenological interpretation. He begins, in a similar tone to this introduction, by justifying a move away from the discourse of Sartrean Existentialism. The unconscious, he argues, is fundamental to the novel, however much the Sartre of that period may have denied its reality in terms of the being for-itself. As such, Nausea teems with material for the psychoanalyst, and Poiana's reading focuses on its potential as a site of (continual instances of) resistance to impulses recognised by the subject as dangerous. The nausea functions accordingly as symptom.

In light of his reading, the drives that Poiana exposes can be seen as subterranean currents running through this volume. For example, his discussion of the importance of substitution - the act whereby, in Freud's view, the subject replaces one object with another in an act of sacrifice before a dangerous impulse - is picked up by the discussion of fetishism in Rolls' chapter. Indeed, both Poiana and Rolls reveal the narrative to be driven by a lack of catharsis, where writing replaces unsatisfactorily - more carnal urges. This concept is also clear in Schehr's chapter where acts of sex are shown to be fleeting, disguised and always disappointing. Where Rolls and Schehr focus on the language of the hands and face, Poiana concentrates his reading around the throat, revealing the famous encounter over lunch to be one of a number of scenes driven by the tension of a pleasure/displeasure binary (in this case, based on ingestion). In his discussion of Roquentin's loss of language, Poiana moves from a Freudian analysis of hysteria towards a Lacanian reading of loss of the expression of desire. He thus shows how the diary works against its own stated purpose: the idea of speaking out, of opening up (to a reader), instead of producing a catharsis, only points to a vague solution that may or may not happen in the future. Indeed, not only does the symptom not abate over the course of Roquentin's production of text, it actually takes over; as he offers up his throat to the symptom, the nausea speaks in his stead. And the very fear that he expresses when confronted with scenes of jouissance (Poiana cites Roquentin's ambivalent attitude towards the Autodidact's submission to his symptom in the library) is ultimately abandoned before the tree root that both disgusts him and holds his gaze. Nausea is shown to be a quicksand that pulls one further in the more one struggles; and the very act of giving

\footnotetext{
${ }^{3}$ In the same way we make free choices because we are free, but it is only through the choices we make that we can be free...
} 
this suffocation the name 'existence' seems to bear witness to the victory of the symptom over the subject.

\section{'Nausea' in Context}

The work of Jean-Paul Sartre, and Nausea in particular, is amongst the most extensively studied in the world and yet there has been remarkably little published about the context within which his work was produced. Indeed, rarely has what Bourdieu describes as the myth of the 'créateur incréé' been better illustrated than in the case of Sartre. On its publication Nausea was greeted by many critics as a work of novelty and originality; they described it as a starting point, oriented towards a future which it would help to construct (Hollier, 2001). The danger is to follow their lead, to refuse to see what links Nausea to its situation.

The theoretical framework provided by Bourdieu's category of the literary and intellectual field leads us to believe that such analysis is essential to a complete understanding of the characteristics of Nausea: its originality, its innovations whether generic or thematic, won out of struggle with existing conventions. This section seeks to fill a gap in scholarship which still remains in relating the novel to its literary and intellectual context and predecessors.

The most extensive attempt to place Sartre within the literary and intellectual field of his time, and one which adopts a Bourdieusian perspective, is Anna Boschetti's Sartre et les Temps modernes (1985) which argued that his dominance resulted from his unique positioning at the summit of both the literary and intellectual fields. As the title suggests, however, Boschetti focusses on the post Second World war decade. The recent collection of articles edited by Ingrid Galster, La Naissance du phénomène Sartre, raisons d'un succès 1938-1945, takes up the debate with Boschetti, who contributes an article to the volume.

La Naissance du phénomène Sartre brings together articles by many leading Sartre scholars and allows us to assess the latest contributions of Sartrean scholarship in this area. The articles help to position Sartre in the intellectual and literary field of his time but concentrate, as the title suggests, on the reception of his works rather than on their production. Moreover, by bracketing together the pre- and immediate post-war period, the articles risk losing sight of the specificity of Nausea. The danger is then to view the novel through the subsequent work of philosophy, Being and Nothingness and to lose sight therefore of both the specifically literary qualities of Nausea and of its possible divergence from the philosophical positions of the later work.

The authors in this section 'Context' attempt, on the contrary, to dispense with the perspectives of hindsight and to seek to understand the emergence of Nausea in relation to the literary and intellectual field of its time - which is not, moreover, the period of its publication, but the twenties and early thirties, when the work was conceived. The challenge is to recognise in the difficulties Sartre encountered as he wrestled throughout the thirties with the text - the difficulty of writing attested in his letters to de Beauvoir and the length of its gestation - his struggle to carve out his own space within the framework of the literary field: the articles in this section seek to identify the influences accepted or rejected, the forms adopted or transformed, the references whether implicit or explicit to other works.

Denis Hollier defines the challenge of understanding Nausea as that of identifying: "la transgression de la loi du genre sous tous ses aspects (un non- 
conformisme à la fois générique et génétique) [qui] est sans doute le véritable noyau générateur de La Nausée [the transgression of the law of genre in all its aspects (nonconformism, both generic and genetic) which is no doubt the true generative kernel of Nausea]" (Hollier, 2001: 95). What were the generic forms, the literary styles available to Sartre as he began his career as a writer? What hierarchy of genres might have dictated his choices, what themes were seen as valid, which predecessors might be called on to legitimise his enterprise? How did he mark his difference from the accepted norms? Only a close textual reading of Nausea in the context of the literary and intellectual field of the early twentieth century can begin to answer such questions.

The challenge in relating Nausea to its context lies in the limitless extent of that context: whether literary or philosophical, political, social or personal. The scope of his reading attested to by Words, his studies within and outside the academy, the influence of the dominant literary movements of his youth, especially surrealism, his work as a teacher and occasional lecturer (Cohen-Solal (1999: 186) draws attention to his lectures on contemporary American fiction at Le Havre library for example), his philosophical studies in Berlin, all these aspects of his personal and intellectual itinerary are relevant. The topic certainly deserves a book to itself, yet here we are able only to hint at some of the less explored aspects of the context of his early work.

The question of the title affords perhaps a way into the discussion to which these chapters contribute. As is well known, Nausea was not Sartre's choice at all: the text submitted to Gallimard was entitled Melancholia. If inspired by the Dürer engraving, the romantic overtones associated with this term are also strong: mélancolie, spleen, ennui (the latter term appears in notes for the early drafts [Sartre, 1981: 1684]) - who could pretend that the distaste for ordinary life, the sense of monstrous otherness, the self-absorption, are not tropes of the nineteenth-century Romantic and post-Romantic literature in which Sartre was steeped?

The boredom and frustration of the long days spent in front of a blank sheet of paper. The contempt for the bourgeoisie, their respectability, their rituals, their smugness and philistinism; the condemnation of art that flatters and gives them a good conscience, that hides their faults. The music that saves the world, the creator and the singer. The final project of writing a novel which will be as bright and hard as a diamond and will make people ashamed of their existence: "le salut auquel aspire Roquentin, in fine, est celui de l'artiste qui oppose à la pesante et fade contingence de l'existence le fil tranchant de l'œuvre d'art" - "the salvation to which Roquentin aspires is, in the end, that of the artist who opposes to faded, heavy existence the sharp cutting edge of the work of art" (Contat, 2001: 32) - even if Roquentin is not too sure of realising salvation himself.

But rather than Romantic, to be more precise, Nausea is redolent of late Romanticism: the disenchanted Romanticism of the late nineteenth century which finds expression in the symbolist project of Mallarmé - the poet who will be for Sartre the exemplary figure of the writer in search of the absolute (Sartre, 1986). Critics have not, in our view, paid enough attention to the persistence into the post First World War decades of the symbolist conception of art and the artist: it is not merely a nineteenth century mode relegated to the museum of literary movements but is represented by one of the best known writers of the period: André Suarès. Rechniewski seeks to trace the parallels between the preoccupations of this second generation symbolist writer and Sartre's literary and philosophical works of the thirties. Through close textual analysis and broad conceptual comparisons she demonstrates that the two writers share a vision of the world which had developed in the second half of the nineteenth century 
amongst the artists and writers of the restricted field of literary production, and which had its roots in the growing alienation of artist and public during this period.

The most fundamental expression of alienation is found in the unresolvable antagonism of contingency and the absolute, an antagonism which can be seen to be at the heart of the contributions to this section. For Contat and Rybalka, the preoccupation with contingency is the central tenet of Sartre's thought, his early writings are essentially an exploration of the theme (Contat \& Rybalka, 1980: 1661). Beauvoir refers in Mémoires d'une jeune fille rangée to the 'theory of contingency' that Sartre was elaborating in 1929 and which contained "déjà en germe ses idées sur l'être, l'existence, la nécessité, la liberté [already in germination his ideas on being, existence, necessity, freedom]" (Beauvoir, 1958: 342). When Sartre began work in 1931 on what was to become Nausea he described it in as his 'factum on Contingency'.

But Beauvoir claims that Sartre could find no inspiration in previous models and that she was surprised at the naivety of his attempts as he struggled to express this theme in literary form (ibid). Contat and Rybalka refer to his reflection on contingency as "le noyau d’originalité le plus décidé, le fondement le plus radicalement personnel et c'est à cette intuition originaire qu'il cherche des confirmations dans ses lectures littéraires et philosophiques [the most pronounced kernel of originality, the most radically personal foundation and it is to confirm this original intuition that he searches in his literary and philosophical readings]" (Contat \& Rybalka, 1980: 1660). Rechniewski contests, however, the originality of Sartre's formulation of contingency, arguing that it had found highly developed metaphorical, literary and conceptual expression in earlier writers.

This fundamental antagonism finds expression in other forms of alienation: to extend the model of the romantic vision of the world, developed by Sayre and Löwy we can identify alienation from the self, from others and from the world. The other chapters in this section illustrate these forms of alienation: Crawley-Jackson explores the alienation that awaits Roquentin at his journey's end, in the city. Falzon's chapter suggests that Roquentin's impossibly strict demand for meaning has its roots in his alienation from others and their constructed social meanings.

Falzon argues that Nausea allows Sartre to undertake a radical philosophical critique of existing beliefs, to explore the limits of previous theories of the foundation of meaning: Descartes, Hegel, Husserl. Roquentin's process of discovery is an exploration of the travails and the limits of consciousness and the gradual revelation of the fragility of the categories and concepts on which unreflecting consciousness is based. But on what sure ground can meaning be founded? As against Descartes, Roquentin's exploration of the cogito results not in certainty but in doubt. Introspection is not a 'safe place' a fortress of sure knowledge, but a place of irreality, of surreal images and nightmarish landscapes.

Husserl's 'philosophical reduction', the "suspension of all empirical existential considerations and all a priori assumptions about entities external (transcendant) to experience" in order to transform my own consciousness into a transcendental consciousness, or transcendental subjectivity, transcendentally purified stream of experiences from which a genuinely phenomenological constitution of the world can begin (Pivcevic, 1970: 65) is also shown to be an inadequate basis for founding meaning. In Nausea the things in themselves haunt and colonise consciousness, they refuse to be purified and tamed, to reveal their transcendental meanings.

Falzon argues that Nausea - through its implicit rejection of these attempts at founding meaning - clears the way for Sartre's own philosophical account of being. 
Being and Nothingness presents itself as the overcoming of this negative stage through postulating a radically free subject that exists only insofar as it negates itself and all forms of determinism. But on what basis can meaning now be founded? The heroic subject of Being and Nothingness is a problematic subject indeed. Falzon suggests that Nausea provides the key to understanding the problematic nature of his philosophical position: Roquentin's growing detachment from all forms of social contact and common project, his physical isolation so tellingly described as the novel unfolds, illustrate in a literary form the philosophical consequences of detachment from the meanings created in social contexts. Nausea illustrates the 'phenomenological problem': “it is inevitable that the belief that truth resides in the interiority of Man should create a problem of others" (Pivcevic, 1970: 149). Roquentin has set up an impossibly high criterion - the demand for an absolute foundation - and discards as inadequate 'too human' attempts at constructing meaning.

Crawley-Jackson draws attention to the context of travel and adventure: the myth of the adventurer, the lure of action, these were common themes of the inter-war years - and indeed of Suarès who was fascinated by the man of action and even more by figures such as d'Annunzio who were both men of action and artists. That Sartre wished to foreground the wrestle with the temptation of adventure is made clear by the phrase contained in the publicity band which he himself suggested for Nausea: "Il n'y a pas d'aventures". We remember too that the alternative title that Sartre had proposed, when Gallimard ruled out Melancholia, was Les Aventures extraordinaires d'Antoine Roquentin. If there is to be found there a reference to Robinson Crusoe, as Contat and Rybalka suggest (Contat \& Rybalka, 1980: 1720), it is just as possible that Sartre had the examples of more recent adventurers in mind: the case of Malraux perhaps, who had already contributed so much to the myth of the adventurer through his life and his novels, and yet who had also already done so much to deconstruct it. As early as 1926 Malraux had suggested the futility of the Western fascination with the East, the risk of disintegration of the Western spirit, the malaise of the post-war generation not knowing where to direct their energy, their disenchantment with myths and legends in which they could no longer believe (La Tentation de l'Occident). His early novels: Les Conquérants (1928), La Voie royale (1930), La Condition humaine (1933), if they plunge their protagonists into the extremes of 'extraordinary adventures', they yet suggest the ultimate futility of human action.

Early in Nausea, Roquentin recounts the sudden disenchantment which overwhelms him as he sits in the office of a French civil servant discussing an archaeological mission: on the table, a Khmer statuette. This scene almost certainly echoes that in La Voie royale where Claude describes his project to Albert Rameges, director of the Institut français: on his desk are photographs of Khmer and Cham statues (Malraux, 1976: 201-5). While Claude presses on with his adventure, but discovers in the death of Perken the nullity of human effort, Roquentin returns to France, to the stultifying existence of Bouville, and 'la nausée des fins de voyage'. Crawley-Jackson situates Roquentin's experience within that of the protagonists of Sartre's earlier fiction and compares it to the dystopias that the latter find at their journey's end. If the early protagonists reach a heterotopia of irreconcilable opposites, Roquentin's journey's end is in the stagnant liminality of Bouville. (We should note that Bouville recalls not only 'Boue-ville' but 'Bout-ville'). As the forms of the city disintegrate around him, he is engulfed in the very condition he had sought to escape: ambiguity, incompletenesss, a kind of perpetual in-betweenness, caught for ever in a process of becoming, trapped in the web of process and flux, symbolising the ambiguity of Man who is what he is not and is not what he is. 


\section{'Nausea' as Intertext}

Intertextuality - as a new critical practice for reading text - was born in the late 1960s, the term being coined by Julia Kristeva. The main thrust of intertextuality is an opening up of the term 'text' itself: instead of seeing individual novels, poems, etc. as closed, autonomous systems, Kristeva considers all individual examples of text to belong to one 'text', the whole system linking all its constituent parts to one another. This system of interrelations, she defines as intertextuality. The principal difference between intertextuality and other negotiations of textual networks (such as influence, for example) lies in the emphasis that it places on the active engagement of the reader. Whereas examples of author influence can often be easy to spot (the influential text being clearly signposted in the new text), it is not always clear what purpose they serve or what the reader should 'do with them'. Intertextuality empowers the reader to construct the network outside the parameters of the written text, between one book and another. This practice recalls post-structuralist theories of the writerly reader (Barthes' work is a good example of this), where the reader does not so much understand (read) the meaning of a work as actually generate (write) it. There are various advantages, as far as textual analysis is concerned, that an intertextual approach to text offers over one guided by the principles of author influence: firstly, the reader adopts a broader critical perspective, importing a whole new set of codes which are no longer external to the text, but existent within the broader Kristevan text - to read the novel, poem, etc. under examination); secondly, the reading practice is no longer inhibited by troublesome chronological details (whereas Nausea cannot be influenced by a work written after 1938, the intertextuality linking it to any other text, irrespective of its place in history, can be used to inform a reading of both).

There are clear links between intertextuality and postmodernism; both have radical implications for the concept of identity. Postmodernism has effectively dissolved the structures through which an individual's identity was constructed (Queer theory is a more recent off-shoot of such fluidity, the way in which we view our own sexuality now being far less dependent on binary structures of male/female, hetero-/homosexual, etc.). In terms of textual identity, Kristevan intertextuality brought about a radical change in our attitudes to the objects that we read. Whereas Modernism had already made full use of self-referential writing techniques - readers being constantly made aware of the status of the text that they are reading as fiction intertextuality moved beyond any need for the text to be self-consciously literary. That the text is one piece of literature within one giant text called literature would henceforth be a given: the onus would no longer be on the writer to encode this status into the text (via such techniques as the mise en abyme, for example); instead the references to the broader (inter)text would always already exist to the extent that the reader could recognise them.

And yet, in practice it is not the always the wont of the reader to engage with a text at the level of its intertextual status. As Michel Riffaterre has pointed out (through his work on reader-response theory) the reader can only bring to his or her critical engagement with a given text the sum total of his or her previous reading: clearly no intertextuality can exist between Freud and Nausea for the reader if the reader has not read Freud. As such, the texts that tend to yield the most interesting intertextual analyses are those that expose themselves appropriately to the reader (i.e. 
a text often has to be self-consciously Modernist in order for the reader to be empowered to read it in a postmodern way). Both the works in the 'Text' and 'Intertext' sections of this present volume will reveal Nausea to be such a text.

Whilst work has been done on the postmodern aspects of Sartre and his writing, the tendency has been for Nausea not to figure prominently. In his approach to the subject, for example, Nik Farrell Fox emphasises the standard philosophical landmarks: Being and Nothingness, Critique of Dialectical Reason and Search for a Method. This is only to be expected given the troubled status of Nausea as 'somewhere between novel and philosophy'. Indeed, there are only three references to the novel in The New Sartre. For example, Fox explains how Sartre's theorisation of the self changes progressively (towards postmodernism) throughout his career. He writes as follows of the relationship between identity and the Rollebon project:

Sartre's early work (The Transcendence of the Ego, Nausea, Being and Nothingness) theorizes the subject in isolation from language and presupposes that any linguistic determination of the self will not affect it in any substantive way. This can be seen in Nausea, for instance, when Roquentin becomes aware that his self is not identifiable with the referent 'historian', giving rise eventually to the experience of nausea itself. (Fox, 2003: 22)

There is nothing wrong with what Fox is suggesting. What has happened is that Nausea has (again) been appropriated as a philosophical text. Fox is able to use Nausea this way because there is an understanding shared between him and his readers as to what the text is all about. This is an appropriation of Nausea to a postmodern end, which, perversely, denies the novel its own postmodern identity. For Roquentin's self can be seen to be born directly of the Rollebon project. His very name, Roquentin, can be found in the pseudo-historical evidence from the Rollebon case, which not only draw physical similarities between Rollebon and his historian but also contain the following homonyms: Mlle de Roquelaure and Roquefort cheese (cf. Rolls, 2003). Sartre is deliberately setting Nausea up as a text about texts, made out of texts. This textuality has so often been denied by philosophers for the simple reason that they tend to see the novel as informing the philosophy and become blinded to the alternative. The only other substantive reference to the novel in Fox's text is once again doubly interesting in this respect: firstly, it is a valuable remark (which we should like to see followed up in due course); and secondly, it draws on the famous chestnut tree scene, which has become a metonym for the (frozen meaning of the) novel:

This [the tendency for an 'order of things' to be imposed by the socially and historically conditioned frameworks of human society] is well illustrated in Nausea where Roquentin tries to apprehend the objective, unmediated reality of the roots of a chestnut tree but ends up feeling nausea prompted by the recognition of the stark separation between the brute, viscous reality of the thing and the words and concepts we use to capture it. In this respect it is possible to view Sartre's epistemology in Nausea as a (postmodern) reaction against the (modern) scientific idea of representation in which it is thought that we can authentically represent or 'picture' the true, essential nature of things. (Fox, 2003: 171-2n.13) 
Nausea has not always been appropriated to philosophical ends. It has been adopted by authors of fiction, usually in a way that might more properly be termed influence than intertextuality. One of the most famous, and oft-quoted, examples is the use made of both Nausea and Jean-Paul Sartre as textual import. In his novel L'Écume des jours (1947) Boris Vian showcases grossly caricatural aspects of Existentialism, not so much as philosophy but as post-War phenomenon. Sartre the icon of the Parisian Left Bank becomes Jean-Sol Partre, and his famous conference of 1945 is parodied with ample punning on la nausée, including displays of stuffed vomit being presented to those in attendance. This clearly exposes L'Écume des jours to intertextual analysis via Nausea, and also opens a possibility of importing the novelistic strategies at the heart of Vian's work (back) into Sartre's text. ${ }^{4}$

According to Kristeva's vision on the text, Nausea joined the intertextual network from the very moment that Roquentin was first read. Sartre himself became a truly intercultural artefact a year before the publication of Vian's L'Écume des jours. 1946 saw publication of Robert Scipion's Prête-moi ta plume, a novel-cum-pastiche that presents - through anagrams - the whole cast of the Left Bank at the time of the Liberation. Foremost among these are "les Genpolçarthres" who sit around cafés smoking pipes and 'sucking on nausea'. 5

A less well known example of intertextuality linking a later novel to Nausea can be found in Simenon's novel Maigret et la vieille dame, in which Maigret reminisces about the predictions that were printed in the almanacs of his youth:

Each day of the month was followed by a prediction. One would read, for example:

17 August. Melancholia

18 August. Undertake nothing. Do not travel.

19 August. Morning will be happy, but beware the evening.

(Simenon, 1951: 144 - authors' translation)

The similarity between these lines (right down to the expression of Melancholia, the term that famously stood as title for Sartre's novel before 'Nausea' was finally chosen) and various diary lines from Nausea is striking. The authors in this volume use examples such as these to read Nausea, opening the way into the enormous potential for meaning that intertextuality makes available.

Keryn Stewart's chapter, “II Have Finished Travelling”: Travel, Displacement and Intertextuality in Jean-Paul Sartre's Nausea', displays the way in which a novel can point simultaneously inside and outside the bounds of its own pages. By drawing on the exercises in intertextuality performed by Michel Riffaterre, Stewart provides provocative examples of Nausea's ability - by virtue of its deliberate construction to elicit reader response; and by so doing, she explores the creative potential that lies at the interface of reader and text whilst, at the same time, indicating the power of the novel's construction (the author-text interface) to kindle such production of meaning. It is important to underline this dual perspective, for all too often intertextual analyses fall prey to accusations of seemingly random comparisons being drawn between two unrelated texts. It is the duty of the critic to establish the 'relatedness' of her texts, to establish her intertext. Stewart's choice of David Wilson's novel Love and Nausea will ruffle few feathers; it is a novel that explicitly declares its debt of influence to Sartre's text from the front-cover to the last page. Stewart is thus able to use this link

\footnotetext{
${ }^{4}$ For an example of an intertextual analysis of these two texts, see Rolls 1999.

5 "Fumeurs de pipe [...] et suceurs de nausées, voilà les Genpolçarthres” (Scipion, 1946: 211).
} 
as a seal of approval, drawing on its authority to reverse the flow: the influence that Nausea has on Wilson's novel is put to creative use through the revelation that Love and Nausea can retrospectively inform our understanding of Sartre's text.

Having established the intertextual potential of Nausea - and the fruitfulness of intertextual criticism itself - Stewart is able to steer her work into uncharted, and unexpected, waters. Her examination of Wim Wenders' film Paris, Texas is an exemplar of double-edged intertextual criticism: whilst the parallel drawn between the road movie and Roquentin's diary leads the reader of Nausea out of the novel in search of new illumination, there is a constant pull back to the novel. For Stewart is able to demonstrate how her intertext, far from inventing meaning ex nihilo, highlights words that are already there.

Given the revelations of the essays in this volume, one might wonder whether Nausea is a novel in good or bad faith. This is an extremely difficult question to answer, especially since bad faith itself is such a complicated term. It is this very question, however, that Debra Hely asks implicitly in 'Fact or Fiction? Reading through the Nothingness behind Nausea'. Implicitly - because the concept of nothingness is her starting point, just as it lies at the heart of every role that our consciousness plays in our every dealing. And our ability to be in bad faith - that is, our ability to lie to ourselves - depends upon this void that separates us from ourselves. This void is, of course, nothing, which makes the very concept of lying to oneself more complicated than it may at first appear. In his study of bad faith as expounded in Being and Nothing, Marc Wetzel explains that the standard definition of this concept as a case of 'lying to oneself' depends on an understanding of what it means to 'lie', which is less clear than first appears:

Indeed, the essence of lying implies that the liar is completely aware of the truth that he is disguising. One does not lie about what one does not know; one does not lie when one propagates an error to which one has oneself fallen victim; and neither is one lying when one is mistaken. [...] The liar's intention is to deceive, and he does not seek to hide this intention or to mask the translucidity of consciousness. (Wetzel, 1985: 49 - authors' translation.)

And yet it is not Hely's purpose here to examine the nature of truth. Neither is it to ascertain to what extent the author/narrator is duped by his own game. Rather she takes it as a given that this nothingness that intervenes between us and the world in which we are situated (that which simultaneously joins us to it and distances us from it) is the same as that which distances the reader from the text that she is reading.

Not only can we not be sure whether or not the facts being divulged are true; we cannot know either to whom the truths or lies are being told. This parodied diary form introduces a duality into the consciousness of the narrator: in terms of bad faith, Roquentin is set up as the teller (writer) of the lie and the receiver (reader) of the lie. This is a duality that the structure of the Sartrean self does not appear to allow: "[...] In bad faith it is from myself that I mask the truth. Therefore the deceiver/deceived duality does not exist here" (Wetzel, 1985: 50). As the Autodidact will rightly point out, one writes with an audience in mind. And, as a writer writing to be read, Roquentin inverts the strategies of the Autodidact whose aim is to read in order to find that his thoughts have already been written. In appearing to lie to himself (to be in bad faith), Roquentin is lying to his reader, transferring responsibility for the truth of the text onto us. And in so doing, he is offering to the reader the truth of our 
existence in the world: as the world only offers a truth that is relative, and which hinges upon our interpretation of it, so too the facts on which Nausea is constructed have no basis in some empirical concept of truth. This is, as we have already suggested, the paradox of the philosophical novel: it is only as hard as steel inasmuch as it responds entirely to the plans written by its author. If Nausea only means what Sartre wants it to mean, then it can appeal to some idea of purity. But the intertextual reading puts the reader to the forefront; it is she who makes the novel 'mean something'. Yet clearly it is not enough just to say that 'everything is relative'. Hely takes this as her starting point, and seeks to reveal how Sartre-Roquentin consciously exploits, or points up, this relationship by offering a selection of details that correspond to or diverge from what may be considered historical accuracy in various degrees. She takes the examples of the recordings to which Roquentin listens, comparing lyrics and biographical details to historical records. And by revealing the surprising incoherence of Roquentin's account, she applies the concept of the unreliable narrator to other aspects of his relations in the text. In Hely's chapter, intertextuality is thus shown to reflect the nothingness that is around the novel, that is the novel in the sense that it is the meeting point where reader and author negotiate meaning.

It is this same concept - of the convergence on the pages of the book of the author and reader - that subtends 'Seduction, Pleasure and a Laying on of hands: A Hands-on Reading of Sartre's Nausea'. Indeed, the aim of this chapter is to draw attention to the novel's self-referentiality, demonstrating the affective power that is released through the process of reading. Those passages that declare themselves to be conscious of their own literariness have a double role vis-à-vis the reader that can be compared to the role played by nothingness, as analysed by Debra Hely: they point up the way in which the text links the reader to Roquentin's tale, situating her within it, whilst at the same time acting as a barrier, forever holding her at bay with the same film of words that draws her in. The fact that the novel resides in this secretion of words that exist ultimately both inside and outside the text - that are and are not the text - serves to posit the reader in a relationship with Nausea that may be said to intertextual.

This is not an intertextual reading in quite the way that Stewart's paper is; an illumination of Nausea is not sought via a text written by another author. The material that is imported into Nausea is largely that provided by Sartre himself. This sounds a little like traditional Nausea criticism: the novel can be understood in the philosophical terms outlined in Being and Nothingness. And yet, the aim of this chapter is to show that the philosophy that lies outside Nausea (i.e. concepts that are not fully expounded explicitly in the novel - concepts other than contingency and superfluity, etc.) is brought into it by the reader. Reader response itself is seen to be something wilfully set up by the author. The novel, through its pervasive use of selfreferential techniques, constantly spills beyond its own pages; its meaning appears to become frozen and known by the reader. And whilst only the reader who reads the text freely, who engages head-on with the seductive text, can know its secrets, the text reserves the right to reel back in its being-for-the-reader, both violating the bond of trust and making the reader feel the frisson not only of reading but of being read. This is not simply a case of philosophy in a novelistic wrapping; the novel, in our approach to it and its appeal to us, reveals itself in the colours of the ontological struggle that is our lot as beings in the world. This is a case of intertextuality as existential reading praxis. 


\section{$\underline{\text { References }}$}

Beauvoir, S. (1958) Mémoires d'une jeune fille rangée. Paris: Gallimard.

Cohen-Solal, A. (1999) Sartre : 1905-1980. Paris: Gallimard.

Contat, M. (2001) 'Sartre et la gloire', in I. Galster (ed) La Naissance du phénomène Sartre, raisons d’un succès 1938-45, 29-41. Paris: Seuil.

Contat, M. and Rybalka, M. (1980) ‘La Nausée : Notice’ (Sartre: 1981, 1657-78).

Fox, N. (2003) The New Sartre: Explorations in Postmodernism. New York; London: Continuum.

Hewitt, N. (1982) “'Looking for Annie”: Sartre’s La Nausée and the Inter-War Years', Journal of European Studies 12, 96-112.

Hollier, D. (2001) 'La Nausée, en attendant', in I. Galster (ed) La Naissance du phénomène Sartre, raisons d'un succès 1938-45, 86-100. Paris: Seuil.

Malraux, A. (1976) La Voie Royale, Romans. Paris: Gallimard.

Pivcevic, E. (1970) Husserl and Phenomenology. London: Hutchinson.

Rolls, A. (1999) The Flight of the Angels: Intertextuality in Four Novels by Boris Vian. Amsterdam; Atlanta: Rodopi.

Rolls, A. (2003) “"This Lovely, Sweet Refrain”: Reading the Fiction back into Nausea', Literature and Aesthetics - The Journal of the Sydney Society of Literature and Aesthetics 13 (2): 57-72.

Sartre, J.-P. (1981) Euvres romanesques. Paris: Gallimard.

Sartre, J.-P. (1986) Mallarmé: La Lucidité et sa face d’ombre. Paris: Gallimard.

Sartre, J.-P. (2000) Nausea. London: Penguin. (All references to Nausea in this volume will be taken from this edition.)

Sayre, R. and Löwy, M. (1983) 'Figures du romantisme anti-capitaliste', L’Homme et la société 69-70: 99-112.

Scipion, R. (1946) Prête-moi ta plume. Paris: Gallimard

Simenon, G. (1951) Maigret et la vieille dame. Paris: Presses de la Cité.

Suarès, A. (1921) ‘Pour Gabriel d’Annunzio’ Écrits nouveaux, t. VII: 3-7.

Wetzel, M. (1985) Sartre : La mauvaise foi (L'Être et le Néant). Paris: Hatier. 